\title{
O gênero Evolvulus L. (Convolvulaceae) no município de Morro do Chapéu, BA, Brasil ${ }^{1}$
}

\author{
Maria Elizangela Ramos Junqueira ${ }^{2,4}$ e Rosangela Simão-Bianchini ${ }^{3}$
}

Recebido em 3/11/2004. Aceito em 29/07/2005.

\begin{abstract}
RESUMO - (O gênero Evolvulus L. (Convolvulaceae) no município de Morro do Chapéu, BA, Brasil). Este trabalho trata do estudo taxonômico das espécies de Evolvulus L. encontradas no município de Morro do Chapéu, situado na Chapada Diamantina, no Estado da Bahia. Foram encontrados 12 taxas de Evolvulus: E. argyreus Choisy, E. echioides Moric., E. elegans Moric., E. glomeratus Nees \& Mart., E. gnaphalioides Moric., E. gypsophiloides var. confertus Choisy, E. jacobinus Moric., E. latifolius Ker Gawl., E. linarioides Meisn., E. linoides Moric., E. pohlii Meisn. e E. pterocaulon Moric. Este trabalho é a primeira citação de E. argyreus para o Brasil e propõe o restabelecimento de E. echioides e de E. gypsophiloides var. confertus. Inclui chave de identificação para as espécies, descrições e ilustrações para cada uma delas.
\end{abstract}

Palavras-chave: Evolvulus, Convolvulaceae, Chapada Diamantina, florística, Morro do Chapéu

\begin{abstract}
The genus Evolvulus L. (Convolvulaceae) in Morro do Chapéu Municipality, Bahia State, Brazil). A taxonomic treatment of the species of Evolvulus L. from Morro do Chapéu, on the Chapada Diamantina, Bahia, is presented. The floristic survey revealed 12 Evolvulus taxa: E. argyreus Choisy, E. echioides Moric., E. elegans Moric., E. glomeratus Nees \& Mart., E. gnaphalioides Moric., E. gypsophiloides var. confertus Choisy, E. jacobinus Moric., E. latifolius Ker Gawl., E. linarioides Meisn., E. linoides Moric., E. pohlii Meisn. and E. pterocaulon Moric. This is the first report of E. argyreus for Brazil. We propose the re-establishment of E. echioides and E. gypsophiloides var. confertus. An identification key, descriptions and illustrations of the species are given.
\end{abstract}

Key words: Evolvulus, Convolvulaceae, Chapada Diamantina, flora, Morro do Chapéu

\section{Introdução}

A Serra do Espinhaço é constituída por dois blocos principais: a Chapada Diamantina na Bahia e a Cadeia do Espinhaço em Minas Gerais. Estende-se por um conjunto de mais de $1.000 \mathrm{~km}$, na direção norte-sul, desde a Serra da Jacobina (ao norte) na Bahia até a Serra do Ouro Branco (ao sul) em Minas Gerais. Está compreendida entre as coordenadas $10^{\circ}-21^{\circ} \mathrm{S}$ e $40^{\circ}$ $44^{\circ} \mathrm{W}$, com altitudes entre 700 e $2.000 \mathrm{~m}$ (Harley 1995).

A Chapada Diamantina ocupa aproximadamente $15 \%$ do território da Bahia, situando-se na porção central do Estado. Localiza-se entre as coordenadas $10^{\circ}-14^{\circ} \mathrm{S}$ e $40^{\circ}-43^{\circ} \mathrm{W}$, ocupando uma extensão de $70.258 \mathrm{~km}^{2}$ (Bandeira 1995).

O município de Morro do Chapéu, localiza-se ao norte da Chapada Diamantina sendo classificado pelo Ministério do Meio Ambiente - MMA como zona de extrema prioridade para conservação. Além de outras características, o município possui uma tipologia vegetal única de caatinga que não encontra-se representada em nenhuma das outras Unidades de Conservação (Maury 2002).

A família Convolvulaceae compreende 55 gêneros, com 1.930 espécies (Judd et al. 1999). Apresenta-se subdividida em dois grupos baseados nas características da ornamentação da exina do grão de pólen: "Echinoconiae" com pólens espinhosos; "Psiloconiae" com pólens lisos ou granulados (Hallier 1893). É considerada monofilética, sendo reconhecida assim, tanto por características morfológicas (Judd et al. 1999) quanto por características moleculares (Stefanovic et al. 2002).

O gênero Evolvulus conta com cerca de 100 espécies, sendo predominantemente americano, com apenas duas espécies distribuídas em quase todos os continentes: Evolvulus nummularius L. e Evolvulus alsinoides L. Segundo Ooststroom (1934), estas

\footnotetext{
1 Parte da Dissertação de Mestrado da primeira Autora. Bolsa da CAPES

2 Colégio Estadual Polivalente de Feira de Santana, Av. João Durval Carneiro, s/n, Centro, CEP 44100-000, Feira de Santana, BA, Brasil

3 Instituto de Botânica, C. Postal 4005, CEP 01061-970, São Paulo, SP, Brasil

4 Autor para correspondência: elizangelajunqueira@yahoo.com.br
} 
espécies foram originadas na América e, provavelmente devido ao uso como plantas medicinais, foram introduzidas no Velho Mundo.

Evolvulus é originada do latim "evolvo", significando aquele que não se enrola, por não terem sido registradas plantas volúveis no gênero. Caracteriza-se principalmente pela presença de dois estiletes livres ou unidos na base, cada qual com dois estigmas filiformes ou subclavados, os tricomas malpiguiáceos e sementes glabras também estão presentes em todos os representantes. Dentre os gêneros semelhantes a Evolvulus, destacam-se Jacquemontia Choisy e Convolvulus L. que distinguem-se por possuírem apenas um estilete com dois estigmas ovais ou elipsoidais, e Bonamia Thouars que possui estigmas globosos.

Poucos trabalhos sobre Convolvulaceae da Bahia já foram publicados: Falcão (1977) reconheceu sete gêneros e 67 espécies; Harley \& Mayo (1980) referiram sete gêneros e 37 espécies; Harley \& Simmons (1986) listaram seis espécies para a região de Mucugê distribuídas em quatro gêneros; SimãoBianchini (1995) descreveu para o Pico das Almas, no município de Rio de Contas, quatro gêneros e 14 espécies; Simão-Bianchini (1998) levantou para a Serra da Chapadinha três gêneros e quatro espécies e para o morro do Pai Inácio, cinco gêneros e sete espécies; Simão-Bianchini (2003) listou para a região de Catolés oito gêneros e 26 espécies e Junqueira \& SimãoBianchini (2003) identificaram na flora de açudes do Semi-Árido, três gêneros e quatro espécies.

As Convolvulaceae ocorrem em diversos tipos de vegetação, predominando em áreas abertas como cerrado e caatinga, tipos marcantes no semi-árido do Brasil. Joly (1970) ao caracterizar a caatinga refere a família entre as mais importantes e comuns para este tipo de bioma. Segundo Simão-Bianchini (2002) Convolvulaceae destaca-se por apresentar espécies endêmicas para a caatinga.

Este trabalho tem como objetivos contribuir para o conhecimento de Convolvulaceae para as floras da Chapada Diamantina e da Bahia, através do levantamento das espécies de Evolvulus no município de Morro do Chapéu e apresentação de levantamento, chaves de identificação, descrições, ilustrações e comentários sobre os aspectos morfológicos e ecológicos.

\section{Material e métodos}

Área de estudo: O município de Morro do Chapéu possui área de $5.513,4 \mathrm{~km}^{2}$, uma das maiores áreas municipais da Bahia e está seccionado pelas rodovias BA 426 e BA 052 (Bahia 2003). Situa-se entre as coordenadas $10^{\circ} 40^{\prime}-11^{\circ} 50^{\prime} \mathrm{S}$ e $40^{\circ} 50^{\prime}-41^{\circ} 20^{\prime} \mathrm{W}$. O relevo é caracterizado por formas tabulares, dispostas em patamares, que se elevam de 480 a $1.200 \mathrm{~m}$ de altitudes. Os solos apresentam acidez e baixa fertilidade, e predomina o tipo climático Cwb (Köppen 1948), tropical de altitude de verão brando, com temperatura média do mês mais frio (julho) inferior a $18^{\circ} \mathrm{C}$ e temperatura média do mês mais quente (janeiro) inferior a $22{ }^{\circ} \mathrm{C}$ (Rocha \& Costa 1995). A temperatura média compensada equivale a $19,7^{\circ} \mathrm{C}$ e a precipitação média anual geralmente é reduzida, em torno de $800 \mathrm{~mm}$ (Rocha \& Costa 1995). Apresenta várias formações vegetacionais como caatinga (predominante), campo rupestre, mata, "tabuleiro", vegetação de dunas interiores e áreas de transições. Trabalho de campo e material herborizado - Foram realizadas 11 viagens de coletas, durante o período de agosto/2002 a maio/2003, sendo que, em cada coleta mensal eram visitadas pelo menos seis áreas correspondentes a tipos diferentes de vegetação. Além das visitas ao município de Morro do Chapéu, outros municípios da Chapada Diamantina foram também percorridos como Palmeiras, Lençóis, Mucugê e Rio de Contas para observar as variações intra-específicas.

O material coletado foi processado segundo técnicas usuais de herborização (Mori et al. 1989), e também conservado em álcool $70 \%$ e sílica gel. Todo o material, assim como o ambiente onde ocorrem, foram fotografados em filmes de papel ou diapositivo. As exsicatas estão depositadas no Herbário da Universidade Estadual de Feira de Santana (HUEFS), com duplicatas distribuídas, principalmente para o Herbário Maria Eneyda P. Kauffmann Fidalgo (SP).

Além dos materiais depositados no HUEFS e obtidos com coletas próprias foram examinados materiais oriundos dos Projetos "Flora da Bahia", "Projeto Chapada Diamantina (PCD)", "Flora dos Campos Rupestres (CFCR)" e "Instituto do Milênio do Semi-Árido" (IMSEAR) e coleções dos seguintes herbários: ALCB, BHCB, CEN, CEPEC, EAC, ESA, HB, HRB, HST, HUFU, HUNEBA, IAC, IPA, LPB, MAC, MBM, MBML, MG, R, RB, SP, SPF, TEB, UEC, UFMT (acrônimos de acordo com Holmgren et al. 1990).

Tratamento - Para os termos morfológicos nas descrições das partes vegetativas e das inflorescências e partes florais seguiu-se Radford et al. (1974); para o indumento seguiu-se Harris \& Harris (1997). 
Para as medidas do comprimento de estiletes e estigmas foi necessário definir a região receptiva no gineceu, e então, foram realizados testes químicos para avaliar receptividade estigmática, utilizando-se água oxigenada e protocolo de alfa-naftil acetato para testar a presença de atividade de esterase adaptado de Dafni (1992). Foi estabelecido que a região estigmática é toda área localizada logo após a bifurcação dos ramos, sendo formada por papilas.

A identificação dos táxons foi baseada em bibliografia especializada, exame das coleções, fotos dos tipos nomenclaturais provenientes do Field Museum (F), e do Kew Royal Botanical Garden (K). Além disso, foram analisados microfilmes do material original de Convolvulaceae citadas no Prodomus Systematis Naturalis de De Candole (Choisy 1845) e depositados no Instituto de Botânica de São Paulo (SP).

As ilustrações foram feitas em câmara clara acoplada a estereomicroscópio. Está sendo citado como testemunho apenas um exemplar selecionado de cada táxon, e dois quando um material possui apenas flores e o outro apenas frutos, porém listagem completa pode ser solicitada à primeira autora.

\section{Resultados e discussão}

O município de Morro do Chapéu apresenta 12 espécies de Evolvulus, um número representativo tanto quando comparado com o total de 26 espécies de Convolvulaceae identificadas até o momento, quanto ao se comparar com outras áreas já estudadas da Chapada Diamantina e da Bahia, uma vez que para a Bahia são citadas 23 espécies do gênero por Falcão (1977); para o Pico das Almas (Rio de Contas) foram encontradas sete espécies (Simão-Bianchini 1995), sendo E. elegans, E. glomeratus, E. jacobinus e E. pterocaulon comum às duas áreas; a Serra da Chapadinha (Lençóis) com duas espécies (SimãoBianchini 1998) sendo E. jacobinus comum às duas áreas; o Morro do Pai Inácio (Palmeiras) com duas espécies (Simão-Bianchini 1998), sendo E. jacobinus comum às duas áreas; o município de Mucugê com duas espécies (Harley \& Simmons 1986); a região de Catolés (Abaíra) com oito espécies (Simão-Bianchini 2003), sendo E. glomeratus, E. jacobinus, E. latifolius, E. linoides presente em ambas; a região de Açudes do Semi-Árido (Feira de Santana e Anguera) apenas com a espécie E. filipes (Junqueira \& Simão-
Bianchini 2003), que não ocorre em Morro do Chapéu.

O trabalho identificou características que não eram tradicionalmente utilizadas para a identificação dos táxons em níveis específicos como tamanho dos estiletes, tamanho da bifurcação dos estiletes e forma dos estigmas, bem como observou a presença em algumas espécies de apêndices laterais arredondados na base dos filetes e a presença de vesículas epidérmicas nas anteras.

\section{Evolvulus L.}

Espécie-tipo: Evolvulus nummularius L. Sp. pl. 2: 391. 1762.

Ervas ou subarbustos, eretos, prostrados ou estoloníferos, nunca volúveis; indumento seríceo, viloso, lanoso, tomentoso ou lanuloso, denso ou glabrescente; tricomas tectores malpiguiáceos, ramos de tamanhos muito diferentes até iguais, raro tricomas glandulares. Folhas simples, elípticas, ovais, lanceoladas, lineares, oblongas, orbiculares ou obovais, margem inteira, plana ou revoluta, ápice agudo, acuminado, arredondado ou emarginado, pontuações presentes ou ausentes, nervação acródroma basal imperfeita, broquidódroma, camptódroma ou hifódroma, sésseis ou pecioladas. Inflorescência indeterminada, tirso racemiforme, corimbiforme ou espiciforme, axilares ou terminais; bractéolas duas, opostas, raro numerosas e verticiladas devido a redução da inflorescência. Flores monoclinas, actinomorfas; sépalas 5, livres, margem escariosa presente ou não; corola gamopétala, áreas mesopétalas evidentes, glabrescentes, seríceas ou denso seríceas externamente, infundibuliforme, hipocrateriforme ou rotácea, limbo inteiro, superficialmente ou profundamente lobado, branco, azul ou lilás, [amarelo em E. paniculatus (Kunth.) Spreng.], prefloração induplicado-contorta. Estames 5, alternos aos lobos da corola, epipétalos, inseridos na base ou próximo à fauce, glabros, bases dos filetes dilatadas, 2 apêndices laterais arredondados presentes ou não; anteras lineares ou oblongas, sagitadas ou cordadas, deiscência longitudinal, introrsa. Ovário globoso, ovóide, cilíndrico, glabro (piloso em E. hasslerianus Chodat); estiletes 2, cada um com dois estigmas; estigmas lineares, subclavados ou raro falcados, papilosos internamente, placentação axial, bilocular, biovulado, raro 4-locular com 1 óvulo por lóculo. Fruto cápsula loculicida, 4 valvar; sementes 4 ou reduzidas por aborto, glabras. 
Chave de identificação para as espécies de Morro do Chapéu

1. Inflorescência espiciforme, compacta; corola hipocrateriforme

2. Folhas decorrentes; inflorescência com todas as brácteas lineares 12. E. pterocaulon

2. Folhas não decorrentes; inflorescência com todas as brácteas semelhantes às folhas ou estreitando-se em direção ao ápice

3. Planta ereta, ausência de gemas desenvolvidas na axila das folhas, sépalas com margem escariosa, estiletes unidos até a metade, estigmas falcados....

2. E. echioides

3. Planta prostrada a semi-prostrada, gemas desenvolvidas na axila das folhas, margem das sépalas não escariosa, estiletes livres, estigmas lineares

4. E. glomeratus

1. Inflorescência tirsiforme, corimbiforme ou racemiforme, laxa; corola rotácea ou subinfundibuliforme

4. Corola profundamente lobada, rotácea

5. Folhas lineares a lanceoladas, margem plana 3. E. elegans

5. Folhas oblanceoladas, margem revoluta 10. E. linoides

4. Corola inteira ou pouco lobada, sub-infundibuliforme

6. Folhas espiraladas, discolores, face abaxial acinzentada 6. E. gypsophiloides var. confertus

6. Folhas não espiraladas, concolores ou levemente discolores, face abaxial verde

7. Pedúnculo evidente, mais de $4 \mathrm{~mm}$ compr.

8. Folhas ovais a elípticas, nervação acródroma imperfeita basal, face adaxial gríseo ou argenteo seríceo-vilosa

1. E. argyreus

8. Folhas lineares a estreito elípticas, nervação hifódroma, face adaxial glabrescente

9. E. linarioides

7. Pedúnculo ausente ou raro até $1 \mathrm{~mm}$ compr.

9. Erva estolonífera; folhas obovais de ápice emarginado 11. E. pohlii

9. Subarbusto ereto ou prostrado; folhas ovais de ápice obtuso a agudo

10. Planta prostrada; folhas cartáceas, denso seríceo-lanosas, prateadas ....5. E. gnaphalioides

10. Planta ereta ou alguns ramos decumbentes; folhas membranáceas; seríceoglabrescentes

11. Folhas 9-12 mm compr., base arredondada, ápice obtuso

7. E. jacobinus

11. Folhas 20-40 mm compr., base cordada, ápice acuminado

8. E. latifolius

1. Evolvulus argyreus Choisy, Mém. Soc. Phys. Genéve 8: 75. 1837.

Fig. 1-6

Erva prostrada, ramos seríceo-vilosos. Folhas cartáceas, ovais a elípticas, 6-15×3-6 mm, ápice agudo a arredondado, margem plana, base cuneada a arredondada, concolores, gríseo ou argenteo seríceovilosas em ambas as faces; nervação acródroma, imperfeita basal; pecíolo 1-2 mm. Inflorescência tirso, brácteas ca. $8 \times 4 \mathrm{~mm}$, elípticas a estreito ovais, ápice agudo, base cuneada, seríceo-vilosas em ambas as faces; pedúnculo 4-16 mm, seríceo-viloso; bractéolas 1,3-1,6 mm, lanceoladas, seríceo-vilosas em ambas as faces; pedicelo 4-8 mm; sépalas lineares a lanceoladas, pontuações ausentes, ca. $3 \mathrm{~mm}$, ápice agudo, margem não escariosa; corola 7-8×11-13 mm, rotácea, levemente lobada, branca, lilás ou azul; filetes ca. $2 \mathrm{~mm}$, glabros, apêndices laterais arredondados, antera ca. 1,3 mm, oblonga, base rotunda, vesícula epidérmica ausente; ovário ovóide a globoso, 0,9-1,0×0,6 mm; estiletes ca. $5 \mathrm{~mm}$, estigmas subclavados, ca. $4,5 \mathrm{~mm}$. Cápsula ca. 3,8×2,0 mm; sementes ca. 3,2×1,8 mm.

Material selecionado: BRASIL. Bahia: Morro do Chapéu, Vilarejo de Brejões, fazenda Formosa, $11^{\circ} 16^{\prime}$, $41^{\circ} 5^{\prime} \mathrm{W}, 9 / \mathrm{X} / 2002$, fl., Junqueira et al. 128 (HUEFS, SP).

Material adicional selecionado: BRASIL. Bahia: Oliveira dos Brejinhos, estrada Oliveira dos Brejinhos - Água Quente, ca. 6 km de Oliveira dos Brejinhos, 15/IV/1999, fl. fr., Amorim et al. 2861 (CEPEC, SP).

Esta é a primeira referência de Evolvulus argyreus para o Brasil, tendo sido coletada apenas na Bahia. A espécie foi descrita para o Equador, onde é muito comum e amplamente distribuída (Austin 1982), distribui-se também pelo Peru, Bolívia, Colômbia e Antilhas (Ooststroom 1934; Macbride 1959; Austin 1982). Em Morro do Chapéu foi encontrada em solos 
rochosos na vegetação de campo rupestre circundada por caatinga. Foi observada em flor nos meses de outubro e março, não havendo registros de frutificação. Em outras áreas da Bahia, floresce nos meses de março e abril, encontrada com frutos apenas em abril.

Evolvulus argyreus caracteriza-se pelas folhas com nervação acródroma basal imperfeita com indumento seríceo-viloso, acinzentado em ambas as faces, e pela presença de apêndices laterais arredondados na base dos filetes. Na área, E. pohlii é a espécie mais semelhante devido ao hábito, distinguindo-se facilmente por apresentar folhas obovais de ápice emarginado, glabras a glabrescentes e presença de pequenas raízes em alguns entrenós.

2. Evolvulus echioides Moric., Pl. nouv. Amér.: 55, t. 37. 1837.

Fig. 7-14

Subarbusto ereto, pouco ramificado, ramos seríceos. Folhas cartáceas, elípticas, raro ovais ou obovais, $20-26 \times 8-12 \mathrm{~mm}$, ápice obtuso a rotundo, margem plana com tricomas patentes, base cuneada, concolores, densamente seríceo; nervação camptódroma; pecíolo ca. $2 \mathrm{~mm}$. Inflorescência espiciforme, brácteas basais $10-15 \times 4-8 \mathrm{~mm}$, eliptícas a ovais, brácteas distais ca. $12 \times 1,5 \mathrm{~mm}$, lineares; pedúnculo ausente; bractéolas lanceoladas, margem escariosa, ca. 2,3 mm; pedicelo ausente; sépalas lanceoladas, seríceas a esparso-seríceas, pontuações ausentes, 5-8 mm, ápice longo acuminado, margem escariosa na porção basal; corola ca.10 mm, 14-20 mm, hipocrateriforme, levemente lobada, azul, base branca; filetes $2,5 \mathrm{~mm}$, glabros, apêndices laterais ausentes, antera ca. 1,7 mm, sagitada, vesículas epidérmicas presentes; ovário globoso, $1 \times 1 \mathrm{~mm}$; estiletes $13-15 \mathrm{~mm}$, estigmas falcados, $8 \mathrm{~mm}$. Frutos não vistos.

Material selecionado: BRASIL. Bahia: Morro do Chapéu, Cachoeira do Ferro Doido, 11³7'39”S, 410'05”W, 8/VI/2001, fl., Souza et al. 99 (HUEFS).

Material adicional selecionado: BRASIL. Bahia: Bonito, caminho de Tabuleiro, estrada para Bonito. 10/X/2002, fr., Junqueira et al. 132 (HUEFS, SP).

É encontrada em Minas Gerais e Bahia. Ocorre sempre em pequenas populações, muitas vezes um único indivíduo e sempre em solo arenoso. Em Morro do Chapéu foi coletado florido em janeiro, junho e setembro, não foi observado frutos até o momento. Em Bonito, município que faz divisa com Morro do Chapéu, foi coletado em frutos no mês de outubro.

Evolvulus echioides Moric. foi sinonimizado sob E. glomeratus subsp. glomeratus var. echioides por
Ooststroom (1934), mas aqui está sendo restabelecido a nível de espécie considerando as diferenças no hábito, ramificação, sépalas, tamanhos dos estiletes e forma dos estigmas. Evolvulus echioides assemelha-se a E. glomeratus mas, difere facilmente por esse último possuir ramos prostrados com gemas pouco desenvolvidas na axila das folhas, folhas mais estreitas, com indumento menos denso, inflorescências mais congestas com brácteas mais estreitas e ausência de margem escariosa nas sépalas.

3. Evolvulus elegans Moric., Pl. nouv. Amer.: 53, t. 36. 1838.

Nome vulgar: muquim (Nova Itarana).

Fig. 15-21

Subarbusto ereto, ramificado; ramos seríceos, glabrescentes. Folhas membranáceas, lineares a lanceoladas, 5-15×1-2 mm, ápice acuminado a agudo, margem plana, base atenuada a cuneada, discolores, face adaxial serícea, verde-escura, abaxial denso seríceo-prateado; nervação hifódroma; pecíolo 0-2 mm. Inflorescência racemiforme ou flores isoladas, brácteas 2-4×0,2-0,6 $\mathrm{mm}$, lineares, lanceoladas, face adaxial serícea, glabrescente, abaxial denso serícea; pedúnculo 1-2 cm, seríceo; bractéolas 1-2 mm, 1-3 pares aproximados devido a redução da inflorescência, pedicelo ca. $2 \mathrm{~mm}$; sépalas lanceoladas, elípticas a ovais, verdes a castanho-esverdeadas, pontuações ausentes, 2-3 mm, ápice agudo a acuminado, margem escariosa; corola ca. 5×7-8 mm, rotácea, profundamente lobada, azul; filetes 1-3 mm, glabros, apêndices laterais ausentes; antera ca. 1,3 mm, base sagitada, vesículas epidérmicas ausentes; ovário ovóide, esférico, ca. $0,6 \times 0,5 \mathrm{~mm}$; estiletes ca. $2,9 \mathrm{~mm}$, estigmas subclavados, ca. $1 \mathrm{~mm}$. Cápsula ca. 2,8×1,6 mm; sementes ca. $2 \times 1,4 \mathrm{~mm}$.

Material selecionado: BRASIL. Bahia: Morro do Chapéu, BA 426, 29 km NE de Morro do Chapéu, caminho a Várzea Nova, 17/I/1997, fl. fr., Arbo et al. $7441 a$ (SP); Vilarejo de Brejões, fazenda Formosa, 9/X/2002, fl., Junqueira et al. 129 (HUEFS, SP).

Espécie com distribuição na Venezuela, Bolívia, Paraguai e Brasil, onde ocorrem nos estados de Paraíba, Pernambuco, Sergipe, Bahia, Minas Gerais, São Paulo, Goiás e Mato Grosso do Sul. Em Morro do Chapéu foi encontrada em áreas de caatinga, em outras regiões ocorre também em campo rupestre, cerrado e em áreas degradadas. Floresce e frutifica, em Morro do Chapéu, nos meses de outubro, novembro e janeiro. De acordo com as exsicatas examinadas para outras regiões floresce e frutifica o ano todo. 


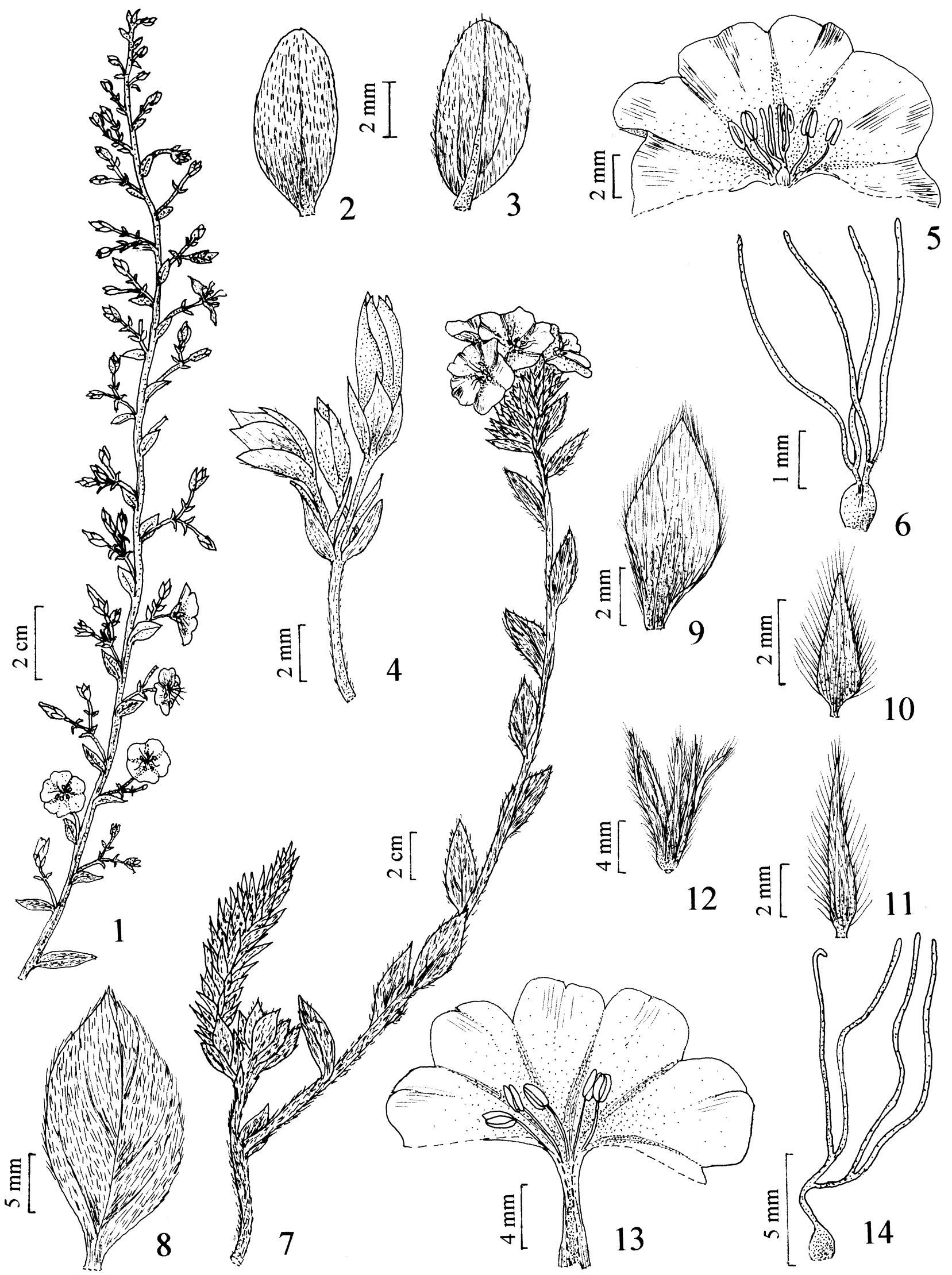

Figuras 1-14. Evolvulus argyreus: 1. Inflorescência. 2. Face adaxial da folha. 3. Face abaxial da folha. 4. Ramo florífero. 5. Corola aberta longitudinalmente. 6. Gineceu (Junqueira et al. 128). Evolvulus echioides: 7. Hábito. 8. Folha, face adaxial. 9. Bráctea basal, face adaxial. 10. Bráctea distal, face adaxial. 11. Bractéola. 12. Cálice. 13. Corola aberta longitudinalmente. 14. Gineceu (E.R. Souza et al. 99). 
Evolvulus elegans caracteriza-se por apresentar folhas pequenas (5-15×1-2 $\mathrm{mm})$ e fortemente discolores, com indumento denso seríceo-prateado na face abaxial, corola profundamente lobada. É uma espécie pouco variável morfologicamente ao longo de sua distribuição. Esta espécie é semelhante a Evolvulus linoides devido ao indumento das folhas e corola profundamente lobada, mas se distingue pelas folhas oblanceoladas, maiores e com margem revoluta.

4. Evolvulus glomeratus Nees \& Mart., Nov. Act. Cur. 11 (1): 81. 1823.

Nome vulgar: sete-sangrias (Iaçu)

Fig. 22-28

Subarbusto prostrado à semi-prostrado, muito ramificado, ramos seríceos, glabrescentes, gemas laterais pouco desenvolvidas na axila das folhas. Folhas cartáceas, elípticas, oblongas, ovais, 12-17×3-5 mm, ápice agudo a acuminado, margem plana, base cuneada a arredondada, face adaxial serícea, glabrescente, abaxial esbranquiçada, nervação camptódroma; pecíolo ca. $2 \mathrm{~mm}$. Inflorescência espiciforme, brácteas basais $8-9 \times 2-4 \mathrm{~mm}$, oblongas, elípticas a ovais, seríceas, brácteas distais 5-5,5×0,7-1 mm, lineares; pedúnculo ausente; prófilos 2, lanceolados, ovais, hialinos na base, ca. 1,7 $\mathrm{mm}$; pedicelo ausente; sépalas lanceoladas, pontuações ausentes, 4-6 mm compr., ápice longo acuminado, margem não escariosa; corola 10-14x 11-16 mm, hipocrateriforme, levemente lobada, azul a lilás, base do tubo branca; filetes ca. $3,5 \mathrm{~mm}$, glabros, apêndices laterais ausentes, antera ca. 1,6 mm, oblonga, base sagitada, vesículas epidérmicas presentes; ovário ovóide a globoso, ca. $1 \times 1 \mathrm{~mm}$; estiletes ca. $8,5 \mathrm{~mm}$, estigmas lineares, 2,0-3,5 mm. Cápsula ca. 1,8×2,0 mm; sementes ca. $1,7 \times 1,3 \mathrm{~mm}$.

Material selecionado: BRASIL. Bahia: Morro do Chapéu, Cachoeira do Ferro Doido, 11³7'39”S, 410'06”'W, 8/VI/2001, fl. fr., Souza et al. 101 (HUEFS).

Esta espécie é encontrada na Guiana, Venezuela, Bolívia, Paraguai, Argentina, Uruguai e Brasil, onde ocorre em quase todo o território, tendo sido referido para Roraima, Pará, Amazonas, Piauí, Ceará, Paraíba, Pernambuco, Sergipe, Bahia, Goiás, Mato Grosso, Minas Gerais, Espírito Santo, Rio de Janeiro, São Paulo, Paraná, Santa Catarina e Rio Grande do Sul. No Morro do Chapéu floresce nos meses de janeiro a junho, tendo sido coletado com frutos em fevereiro e junho. Em outras regiões floresce e frutifica durante todo o ano.

Entre as espécies ocorrentes em Morro do Chapéu, E. glomeratus é reconhecida pelo hábito prostrado a semi-prostrado, pela presença de gemas laterais pouco desenvolvidas na axila das folhas, formando um ramo muito curto com folhas congestas e que não se desenvolve, e pela inflorescência frondoso-bracteosa, com flores sésseis e entrenós reduzidos. Na região é semelhante apenas à E. echioides que difere pelo hábito ereto, pouco ramificado, ausência de desenvolvimento de ramos curtos com folhas congestas, presença de margem escariosa das sépalas e estigmas falcados.

5. Evolvulus gnaphalioides Moric., Pl. Nouv. Amér.: 61, t.41. 1939.

Fig. 29-34

Subarbusto prostrado, ramificado, ramos densolanosos, prateados. Folhas cartáceas, cordiformes, 7-26×4-12 mm, imbricadas, ápice obtuso a agudo, margem levemente ondulada, base cordada, concolores, densamente seríceo-prateadas em ambas as faces, nervação camptódroma; sésseis. Inflorescência axilares, brácteas iguais às folhas, maiores na região mediana da inflorescência; pedúnculo ausente; bractéolas oblanceoladas, densamente seríceo-lanosas, 1,3-4,0 $\mathrm{mm}$; pedicelo filiforme ca. 5,5 $\mathrm{mm}$; sépalas lanceoladas a ovais, ápice agudo, prateadas, pontuações ausentes, ca. $6,0 \times 1,8 \mathrm{~mm}$, margem escariosa ausente; corola 8-12 $\mathrm{mm} \times 12-15 \mathrm{~mm}$, sub-infundibuliforme, levemente lobada, azul; filetes ca. $2,5 \mathrm{~mm}$, glabros, apêndices laterais ausentes; antera ca. 2,4 mm, sagitada, vesículas epidérmicas ausentes; ovário ovóide, ca. $1,1 \times 1 \mathrm{~mm}$; estiletes ca. $4,3 \mathrm{~mm}$, estigmas subclavados, ca. $2 \mathrm{~mm}$. Cápsula ca. $3,2 \times 2,5 \mathrm{~mm}$; sementes ca. $3 \times 2,2 \mathrm{~mm}$.

Material selecionado: BRASIL. Bahia: Morro do Chapéu, Dunas, 10/X/2002, fl. fr., Junqueira et al. 131 (HUEFS, SP); 4/XII/2002, fl. fr., Junqueira et al. 162 (HUEFS, SP)

Espécie rara, endêmica da Bahia, apenas referida para o Morro do Chapéu em dunas interiores, circundada por caatinga, e para a Serra do Açurua, em solos arenosos. Apesar de não ter sido coletada todos os meses do ano nas visitas mensais à região foi observada florida o ano todo.

Evolvulus gnaphalioides é uma espécie muito distinta dentro do gênero, caracteriza-se por toda a planta ser recoberta por indumento densamente lanoso nos ramos e denso seríceo-prateado nas folhas, os ramos são prostrados, as folhas são imbricadas e menores na base. O material coletado na Serra do Açurua, local do tipo, apresenta poucas diferenças em comparação ao material coletado no Morro do Chapéu. $\mathrm{Na}$ Serra do Açurua as plantas possuem as folhas 


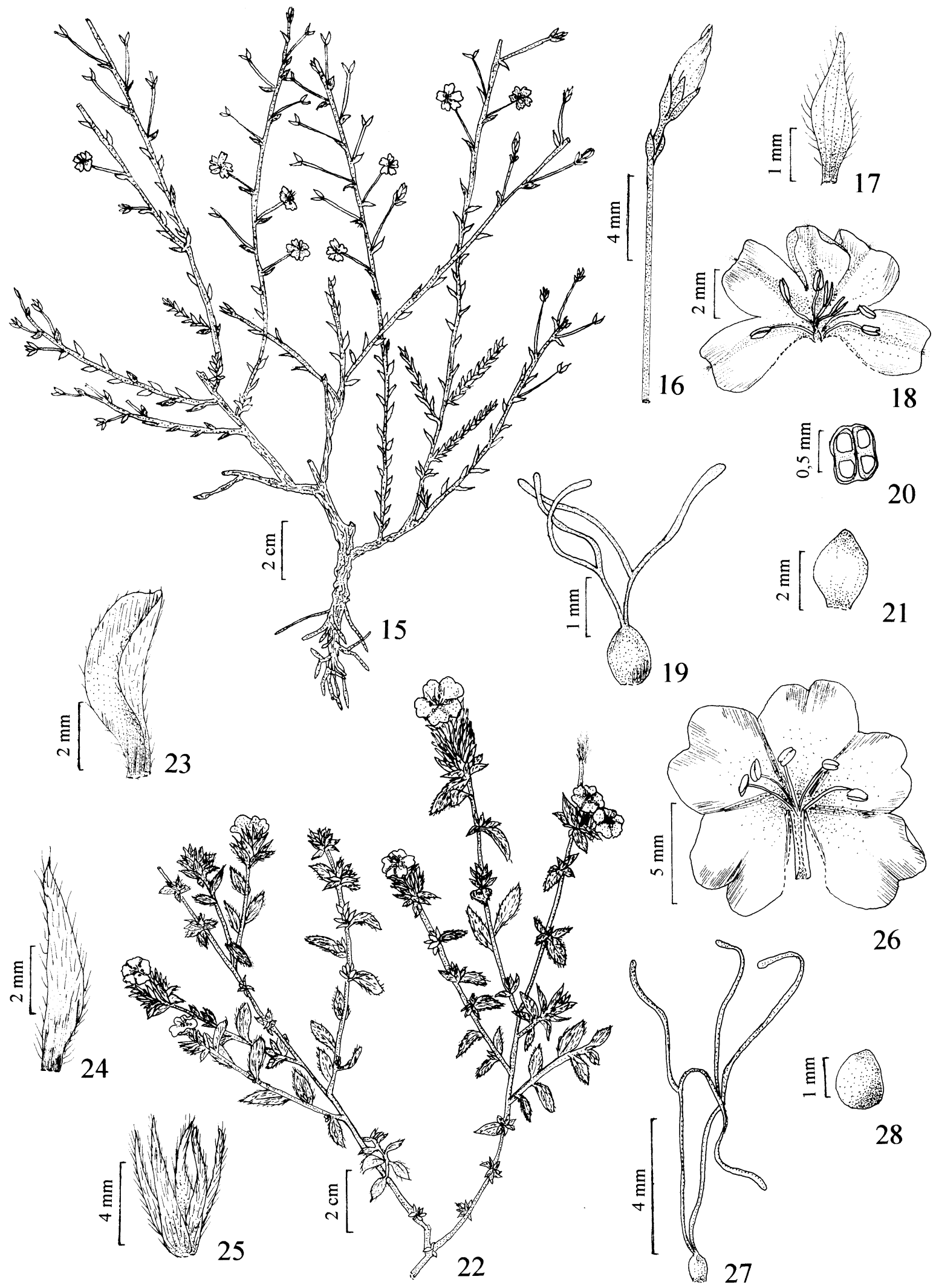

Figuras 15-28. Evolvulus elegans: 15. Hábito. 16. Botão. 17. Sépala. 18. Corola aberta longitudinalmente. 19. Gineceu. 20. Ovário, corte transversal. 21. Fruto (Junqueira et al. 129). Evolvulus glomeratus: 22. Inflorescência. 23. Bráctea basal, face adaxial. 24. Bráctea distal, face adaxial. 25. Cálice. 26. Corola aberta longitudinalmente. 27. Gineceu. 28. Semente (E.R. Souza et al. 101). 
maiores, o indumento menos denso e acastanhado e a coloração branca na base da corola.

Devido à cor prateada do indumento que recobre toda a planta, camufla-se com as areias quartzosas onde ocorre. Observações de campo evidenciaram que em períodos de estiagem suas folhas e ramos encontram-se mais belos e viçosos, por outro lado, logo após a chuva, a planta fica toda queimada, os ramos desidratam e secam, porém após um curto período de seca novos ramos brotam vigorosos.

\section{Evolvulus gypsophiloides var. confertus Choisy} in DC. Prodromus 9: 443. 1845.

\section{Fig. 35-41}

Erva ereta, pouco ramificada, ramos esparsamente seríceos. Folhas espiraladas, lanceoladas, ca. $10 \times 1 \mathrm{~mm}$, ápice acuminado, margem plana, base atenuada, discolores, face adaxial glabrescente, verdeacastanhada, abaxial acinzentada, serícea, nervação hifódroma; sésseis. Inflorescência corimbiforme, 1-3-flora, brácteas 5-6×0,8-1,0 mm; pedúnculo 1,7-4,4 $\mathrm{mm}$; bractéolas lanceoladas, seríceas, 3,8-4,0 mm; pedicelo filiforme ca. 1,8 mm, seríceo; sépalas elípticas a lanceoladas, seríceas, pontuações ausentes, 3-4 mm, margem escariosa; corola ca. 7,4 $\mathrm{mm} \times 8 \mathrm{~mm}$ diâm., sub-infundibuliforme, pouco lobada, alva; filetes ca. $2 \mathrm{~mm}$, glabro; antera ca. 1,4 mm, sagitada, vesículas epidérmicas presentes; ovário cilíndrico, ca. $1,2 \times 0,5 \mathrm{~mm}$; estiletes ca. $4,7 \mathrm{~mm}$, estigmas subclavados, ca. 1,2 mm. Frutos não vistos.

Material examinado: BRASIL. Bahia: Morro do Chapéu, Morrão, próximo ao alto do Morro $1180 \mathrm{~m}$, 16/VII/1979, fl., Hatschbach \& Guimarães 42418 (MBM).

Evolvulus gypsophiloides var. confertus foi registrada apenas para Bahia (Morro do Chapéu e Jacobina).

Evolvulus gypsophiloides var. confertus foi considerado por Ooststroom (1934) como sinônimo de E. ericaefolius Schrank., mas examinando-se materiais de ambas espécies foi possível evidenciar que a variedade descrita por Choisy (1845) possui características de E. gypsophiloides. Evolvulus gypsophiloides var. confertus é caracterizada pelas folhas espiraladas, discolores com face abaxial acinzentada e margem das sépalas escariosas. No Morro do Chapéu, a única espécie semelhante é E. elegans devido ao hábito ereto e folhas discolores e lineares, porém se diferenciam facilmente por E. elegans apresentar os entrenós maiores e, principalmente, pela corola com lobos profundos.
7. Evolvulus jacobinus Moric., Pl. nouv. Amér.: 135, t. 81.1844.

Fig. 42-46

Subarbustos, eretos a decumbentes, muito ramificado, ramos pubescentes. Folhas membranáceas, ovais, elípticas a orbiculares, 9-12×5-11 mm, ápice obtuso, margem plana, base arredondada, concolores, face adaxial rugosa, glabrescente, abaxial esparso serícea, nervação camptódroma; pecíolo ca. $2 \mathrm{~mm}$. Inflorescência axilar, brácteas semelhante às folhas, 11-13×7-8 mm; pedúnculo 0,6-1,0 mm; bractéolas lanceoladas, ca. $2 \mathrm{~mm}$; pedicelo filiforme, ca. $3 \mathrm{~mm}$; sépalas lanceoladas, $4-5 \mathrm{~mm}$, ápice agudo, vináceo, pontuações ausentes, margem escariosa; corola ca. 5,2×9 mm, sub-infundibuliforme, levemente lobada, azul; filetes ca. $1,3 \mathrm{~mm}$, glabro, apêndices laterais arredondados, antera ca. $1 \mathrm{~mm}$, sagitada, vesículas epidérmicas presentes; ovário cilíndrico, ca. $0,8 \times 0,5 \mathrm{~mm}$; estiletes ca. $2,8 \mathrm{~mm}$, estigmas subclavados, ca. 1,2 mm. Cápsula ca. $3 \times 3 \mathrm{~mm}$; sementes ca. $2 \times 2 \mathrm{~mm}$.

Material selecionado: BRASIL. Bahia: Morro do

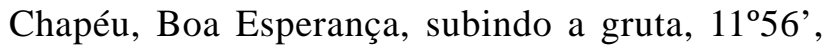
$41^{\circ} 7^{\prime} \mathrm{W}, 5 / \mathrm{XII} / 2002$, fl., Junqueira et al. 175 (HUEFS).

Material adicional selecionado: BRASIL. Bahia:

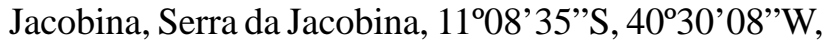
5/VII/1996, fl. fr., Bautista et al. PCD 3428 (HUEFS, SPF).

Esta espécie ocorre apenas no Brasil, sendo comum ao longo da Chapada Diamantina (Bahia), e rara em Minas Gerais, no Espírito Santo só é conhecida por uma referência de Ooststroom (1934). Na Chapada Diamantina cresce sempre em vegetação de campo rupestre. No Morro do Chapéu floresce no mês de dezembro e não foram registrados dados sobre frutificação. Em outras áreas floresce em todo o ano e frutifica nos meses de janeiro, abril, junho, julho, novembro.

Evolvulus jacobinus caracteriza-se por apresentar hábito em touceiras, com ramos eretos a decumbentes e flores quase sésseis.

8. Evolvulus latifolius Ker Gawl., Bot. Reg. 5: 401. 1819.

Fig. 47-51

Subarbusto ereto, ramificado; ramos seríceos. Folhas membranáceas, cordiformes a lanceoladas, 20-40×10-30 mm, ápice acuminado, pouco emarginado, margem plana, base cordada, curto-seríceas; nervação 


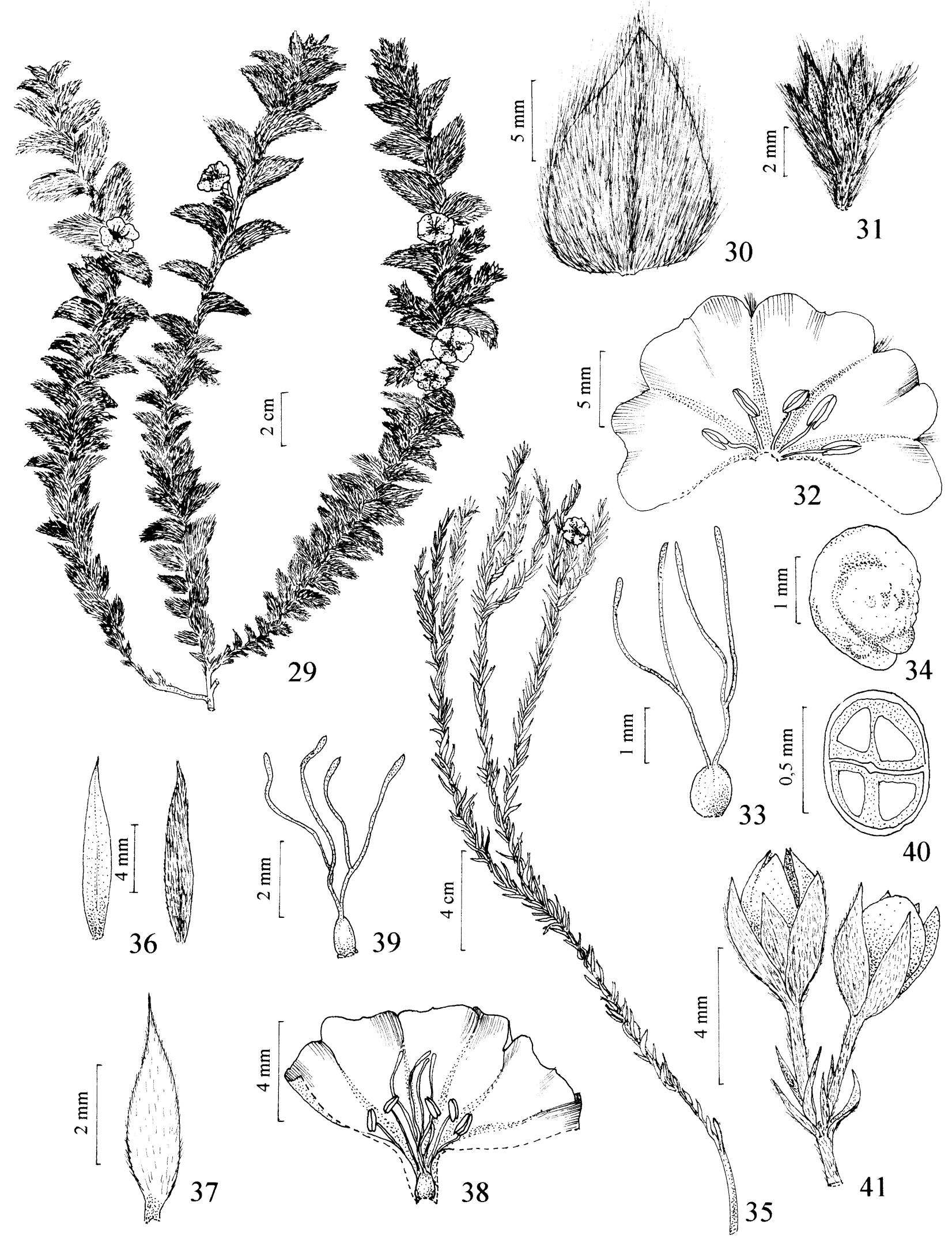

Figuras 29-41. Evolvulus gnaphalioides: 29. Hábito. 30. Folha, face adaxial. 31. Cálice. 32. Corola aberta longitudinalmente. 33. Gineceu. 34. Ovário, (Junqueira et al. 162). Evolvulus gypsophiloides var. confertus: 35. Hábito. 36. Folha, faces adaxial e abaxial. 37. Sépala. 38. Corola aberta longitudinalmente. 39. Gineceu. 40. Ovário, corte transversal. 41. Cápsulas (Hatschbach \& Guimarães 42418). 

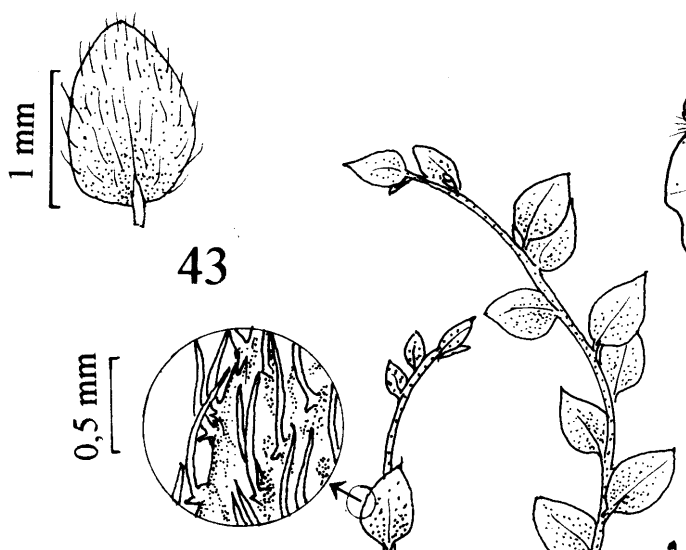

43

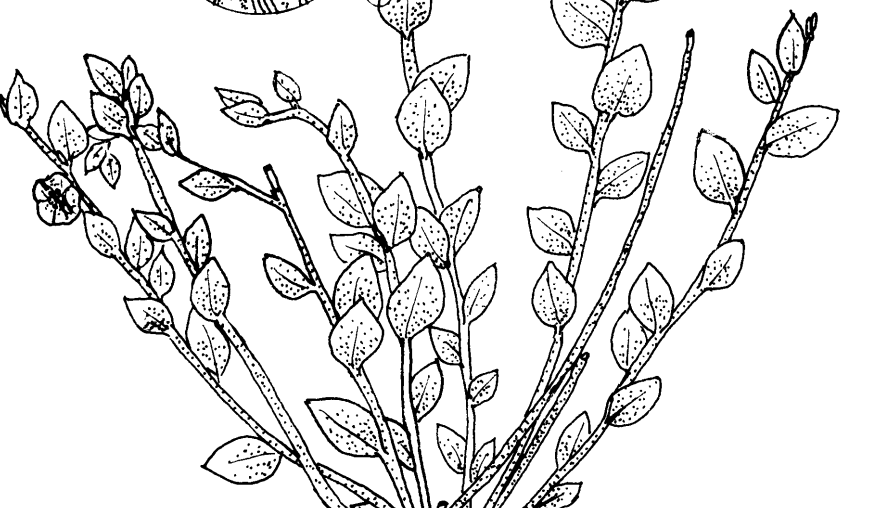

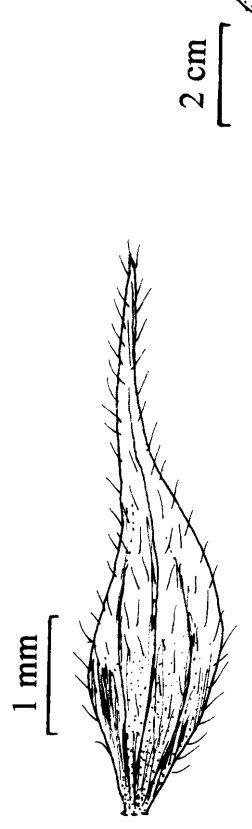

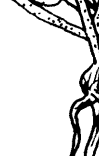

48
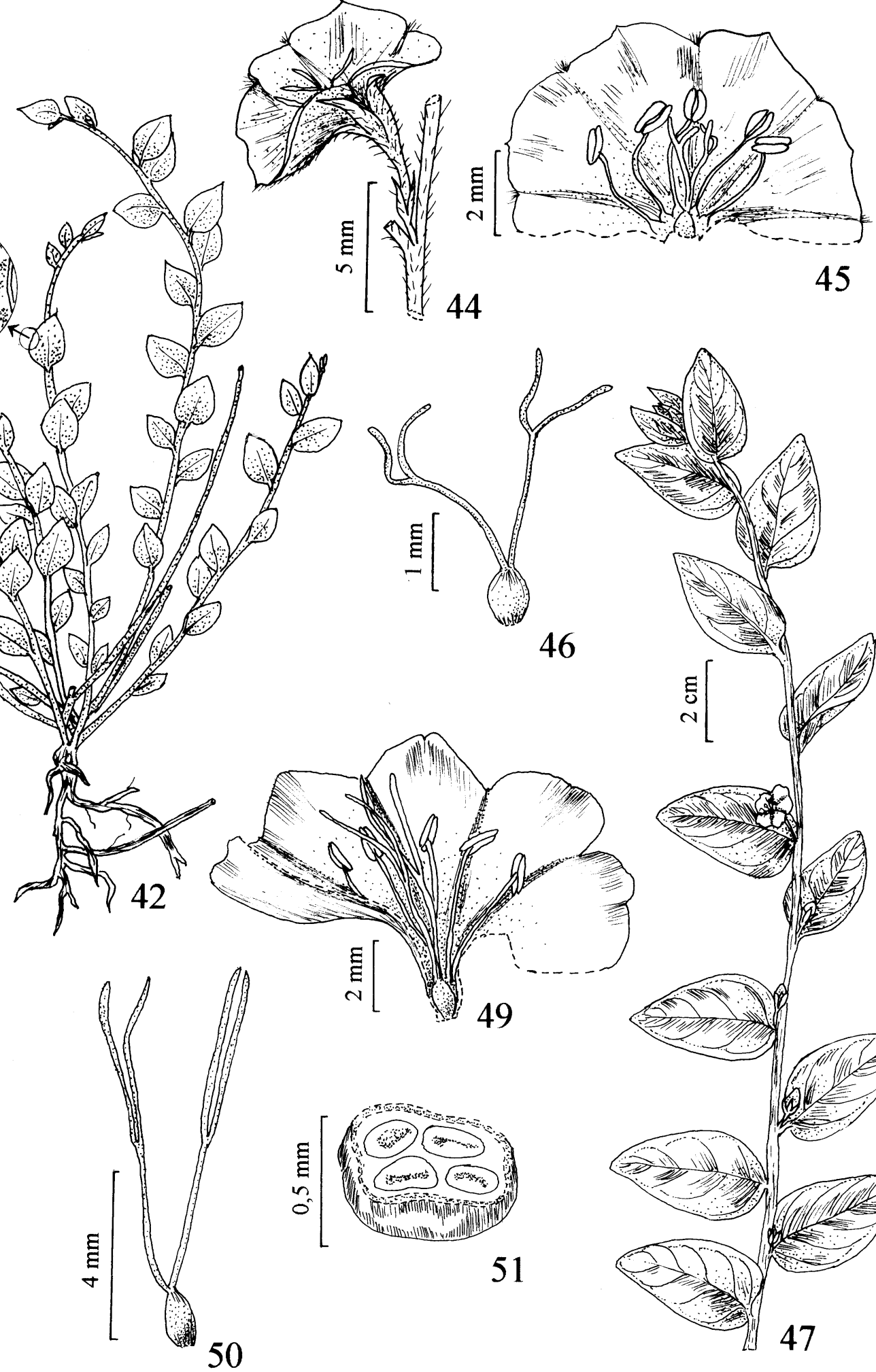

51
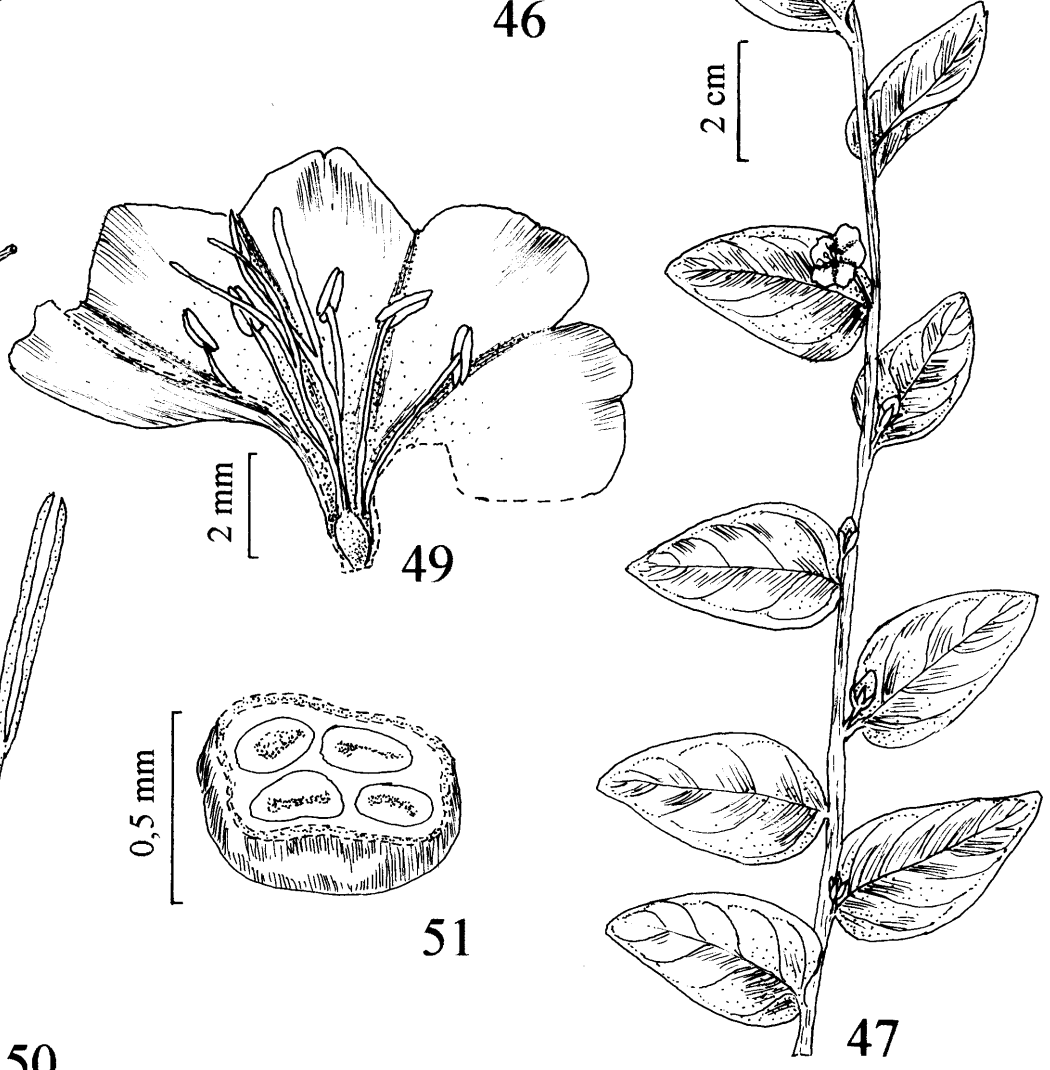

Figuras 42-51. Evolvulus jacobinus: 42. Hábito. 43. Folha, face adaxial. 44. Flor. 45. Corola aberta longitudinalmente. 46. Gineceu (Junqueira et al. 175). Evolvulus latifolius: 47. Inflorescência. 48. Sépala. 49. Corola aberta longitudinalmente. 50. Gineceu. 51. Ovário em corte transversal (Melo et al. 3174). 
broquidódroma; pecíolo 2-3 mm. Inflorescência axilar, 3-7 flores, brácteas ca. $27 \times 14 \mathrm{~mm}$, cordiformes, ápice levemente emarginado, base cordada, ambas faces seríceas; pedúnculo ausente; bractéolas 1-2,6 mm, lanceoladas, seríceas; pedicelo 1,0-1,6 mm; sépalas lanceoladas, seríceas, pontuações ausentes, $4-5 \mathrm{~mm}$, ápice acuminado, margem não escariosa; corola 7-8 $\times 3-7 \mathrm{~mm}$, sub-infundibuliforme, levemente lobada, branca; filetes 2-3 $\mathrm{mm}$, glabros, apêndices laterais ausentes, antera 1,0-1,3 $\mathrm{mm}$, oblonga, base arredondada, vesículas epidérmicas ausentes; ovário ovóide, ca. 1,2×0,6 mm; estiletes ca. $6,9 \mathrm{~mm}$, estigmas subclavados, ca. $3,5 \mathrm{~mm}$. Cápsula ca. $3 \times 3 \mathrm{~mm}$; sementes ca. $2 \times 2 \mathrm{~mm}$.

Material selecionado: BRASIL. Bahia: Morro do Chapéu, 27,5 km SE of the town of Morro do Chapéu on the BA-052 road Mundo Novo, $11^{\circ} 39^{\prime} \mathrm{S}, 41^{\circ} 01^{\prime} \mathrm{W}$, 4/III/1977, fr., Harley et al. 19400 (IPA, SPF, UEC); Rio Ferro Doido, 11³7'0'S, 4059'27'W, 15/XI/1999, fl., Melo et al. 3075 (HUEFS, MBM, SPF); 18/IX/ 1999, fl. fr., Melo et al. 3174 (HUEFS, SP).

Possui distribuição ampla na América do Sul, tendo sido referida para Argentina, Brasil e Paraguai. No Brasil distribui-se pelos estados do Ceará, Pernambuco, Bahia, Minas Gerais, Mato Grosso do Sul, Rio de Janeiro, São Paulo e Paraná. Na Bahia é encontrada em matas e raramente em transição entre caatinga e mata. Floresce no mês de novembro e frutifica no mês de março no município de Morro do Chapéu. Em outras regiões floresce e frutifica praticamente todo o ano.

Evolvulus latifolius caracteriza-se por apresentar hábito subarbustivo robusto, com folhas cordiformes, grandes para o gênero, e flores quase sésseis.

9. Evolvulus linarioides Meisn. in Mart. Fl. bras. 7: 343. 1869.

Fig. 52-56

Subarbusto ereto, ramos seríceos. Folhas membranáceas, lineares a estreito elípticas, 4-5×1-2 mm, ápice agudo, margem plana, base oblíqua, concolores, faces adaxial rugosa, glabrescente, abaxial serícea, nervação hifódroma, pecíolo ca. $1 \mathrm{~mm}$. Inflorescência axilar, 1 flor, brácteas ca. $3 \times 1 \mathrm{~mm}$, lineares a elípticas, glabrescente em ambas as faces; pedúnculo 4-7 mm, seríceo; prófilos 2, lineares, seríceos, ca. 1,7 mm; pedicelo 6-9 mm; sépalas lanceoladas, $3 \mathrm{~mm}$, pontuações ausentes, margem não escariosa; corola ca. $7 \times 8 \mathrm{~mm}$, infundibuliforme, levemente lobada, azul a lilás; filetes ca. 1,8 mm, glabros; antera branca ca. 1,4 mm, apêndices laterais arredondados, sagitada, vesículas epidérmicas presentes; ovário ovóide, cilíndrico, ca. $1 \times 0,8 \mathrm{~mm}$; estiletes ca. $4,3 \mathrm{~mm}$, estigmas subclavados, ca. $1 \mathrm{~mm}$ compr. Cápsula ca. $2 \times 1,8 \mathrm{~mm}$; sementes ca. $1,5 \times 1,2 \mathrm{~mm}$.

Material selecionado: BRASIL. Bahia: Morro do Chapéu, Flores, $11^{\circ} 27^{\prime}$ S, 40²5'W, 03/XII/2002, fl., Junqueira et al. 156 (HUEFS).

É encontrada no Paraguai e Brasil onde ocorre em Pernambuco, Bahia e Minas Gerais. Em Morro do Chapéu cresce em borda de mata, em solos arenosos e caatinga e floresce em dezembro, nesta área a espécie não foi coletada em fruto até o momento.

Evolvulus linarioides caracteriza-se pela folhas lineares glabras a glabrescentes, com pontuações, os pedúnculos maiores que os pedicelos, ambos muito distintos, e apêndices laterais arredondados na base dos filetes.

10. Evolvulus linoides Moric., Pl. nouv. Amér: 139, t. 83. 1844.

Fig. 57-63

Subarbusto ereto, ramificado, ramos seríceos, glabrescentes. Folhas membranáceas a papiráceas, 15-30×10-30 mm, oblanceoladas, ápice subulado, margem revoluta, base atenuada, discolores, face adaxial serícea, abaxial acinzentada densamente serícea; nervação hifódroma; pecíolo ca. $1 \mathrm{~mm}$. Inflorescência axilar, 1-3 flores, brácteas ca. $11 \times 1 \mathrm{~mm}$, lineares, face adaxial serícea, abaxial densamente serícea; pedúnculo 0,5-17 mm, seríceo; bractéolas ca. $0,9 \mathrm{~mm}$, ovais, seríceas; pedicelo 1-26 mm; sépalas ovais, pontuações ausentes, 0,2-0,3 mm, ápice agudo, margem escariosa; corola ca. $8,5 \times 6 \mathrm{~mm}$, infundibuliforme, profundamente lobada, lilás; filetes ca. $2,7 \mathrm{~mm}$, glabros, apêndices laterais ausentes, antera ca. $1 \mathrm{~mm}$, sagitada, base arredondada, vesículas epidérmicas ausentes; ovário cilíndrico, ca. 0,9×0,6 mm; estiletes ca. 4,9 mm, estigmas subclavados, ca. 2,7 mm. Cápsula ca. $4 \times 4 \mathrm{~mm}$; sementes ca. $2 \times 2 \mathrm{~mm}$.

Material selecionado: BRASIL. Bahia: Morro do Chapéu, BA 426, 29 km NE de Morro do Chapéu, caminho a Várzea Nova, 17/I/1997, fl. fr., Arbo et al. $7441 b$ (CEPEC).

Esta espécie ocorre do Brasil (Bahia, Minas Gerais, Mato Grosso do Sul) até a Bolívia. Em Morro do Chapéu foi encontrada em área secundária de caatinga. Só há uma coleta em Morro do Chapéu com flores e frutos no mês de janeiro. Em outras áreas floresce de outubro até maio e frutifica em janeiro, abril e maio.

Evolvulus linoides é caracterizado por possuir folhas estreitas, com margem revoluta, fortemente 


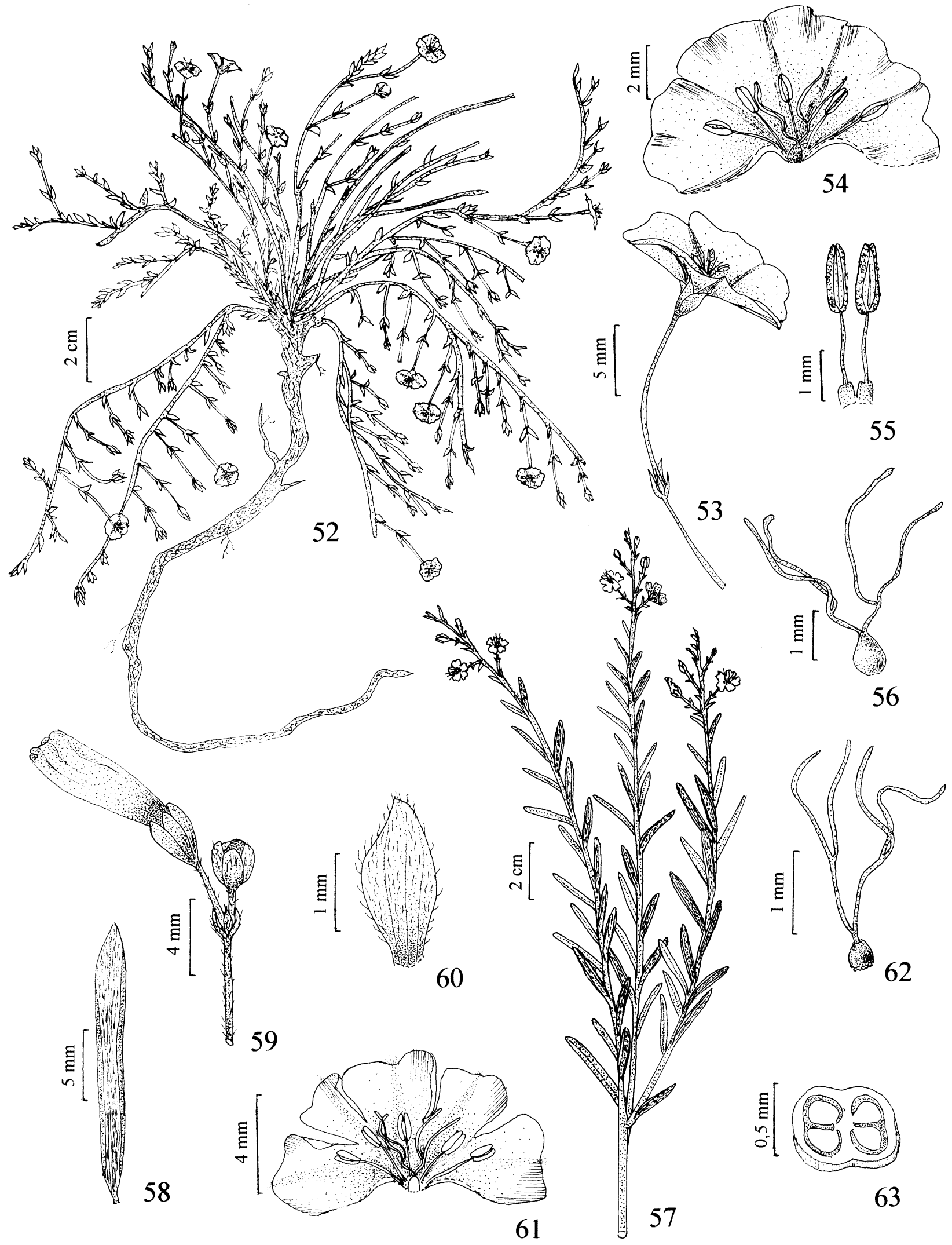

Figuras 52-63. Evolvulus linarioides: 52. Hábito. 53. Flor. 54. Corola aberta longitudinalmente. 55. Estames, detalhe dos filetes com apêndices na base. 56. Gineceu (Junqueira et al. 156). Evolvulus linoides: 57. Inflorescência. 58. Folha revoluta, face abaxial. 59. Ramo florífero. 60. Sépala. 61. Corola aberta longitudinalmente. 62. Gineceu. 63. Ovário em corte transversal (Arbo et al. 7441). 
discolores, com indumento seríceo, e a corola profundamente lobada. É semelhante a E. elegans quanto à coloração das folhas e indumento, diferindo por E. elegans possuir folhas bem menores com margem plana.

11. Evolvulus pohlii Meisn. in Mart. Fl. bras. 7: 334. 1869.

Fig. 64-68

Erva prostrada, estolonífera, ramos lanulosos. Folhas membranáceas, ca. $8 \times 5 \mathrm{~mm}$, obovais, ápice emarginado, margem plana, ciliada, base assimétrica, concolores, face adaxial glabra, abaxial glabrescente, nervação broquidódroma, pecíolo ca. $1 \mathrm{~mm}$. Inflorescência axilar, 1 flor, brácteas $6,5-4,6 \times$ 3,5-5,5 mm, obcordadas, face adaxial rugosa, abaxial glabrescente; pedúnculo ausente; bractéolas lanceoladas, glabrescentes, ca. 1,2 mm; pedicelo 4-14 mm, lanulosos; sépalas ovais, lanulosas, pontuações presentes, ápice agudo, ca. $3 \mathrm{~mm}$, margem não escariosa; corola ca. $6 \times 11 \mathrm{~mm}$, sub-infundibuliforme, branca, lilás a azul; filete ca. $3,6 \mathrm{~mm}$, apêndices laterais arredondados, anteras ca. 1,4 mm, sagitada, base arredondada, vesículas epidérmicas presentes; ovário globoso, ca. $1 \times 1 \mathrm{~mm}$, estiletes ca. $4 \mathrm{~mm}$, estigmas subclavados, ca. 3,5 mm. Cápsula ca. 1,5×2,0 mm; sementes ca. 1,3×0,9 mm.

Material selecionado: BRASIL. Bahia: Morro do

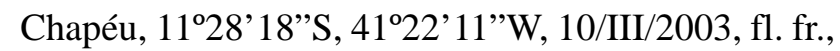
Junqueira et al. 181 (HUEFS).

Espécie com distribuição disjunta no Brasil e México, segundo Ooststroom (1934) as populações do México e Brasil são idênticas, não restando dúvidas para este autor sobre a identificação das populações do México. Evolvulus pohlii no Brasil ocorre na Bahia, Minas Gerais e Distrito Federal. Em Morro do Chapéu foi encontrada em áreas de brejo. É bastante ornamental com potencial para gramado e forragem. Esta espécie foi coletada em Morro do Chapéu no mês de março com flores e frutos, em outros municípios do Brasil floresce de fevereiro a abril.

Evolvulus pohlii possui ramos bastante delicados, é facilmente distinta das outras espécies que ocorrem na área por ser uma erva prostrada com caule estolonífero e folhas obovais de ápice emarginado.

12. Evolvulus pterocaulon Moric., Pl. nouv. Amér: 140, t. 84.1844.

Nomes vulgares: hipepacunha (Morro do Chapéu), rabo-de-raposa (Piracuruca).

Fig. 69-72
Subarbusto ereto, ramificado, ramos seríceos. Folhas decorrentes, diminuindo drasticamente em direção ao ápice, papiráceas, ca. $4 \times 5 \mathrm{~mm}$, lanceoladas, ápice acuminado, margem plana, base oblíqua, concolores, vilosas, nervação camptódroma; pecíolo alado e decorrente no ramo. Inflorescência espiciforme, brácteas ca. $10 \times 5 \mathrm{~mm}$, lineares, vilosas em ambas faces; pedúnculo ausente; bractéolas inconspícuas, ovais, vilosas, 0,4-0,5 mm; pedicelo ausente; sépalas lanceoladas, pontuações ausentes, ca. 5,8 mm, ápice agudo, margem não escariosa; corola ca. $11 \times 11 \mathrm{~mm}$, hipocrateriforme, lobada, azul, branca; filete ca. $0,9 \mathrm{~mm}$, glabro, apêndices laterais ausentes, antera ca. 1,5 mm, sagitada, base arredondada, vesículas epidérmicas presentes; ovário globoso, ca. $8 \times 5 \mathrm{~mm}$; estiletes ca. $9,2 \mathrm{~mm}$, estigmas lineares ca. 2,7 mm. Cápsula ca. $1,5 \times 1,2 \mathrm{~mm}$; sementes ca. $1,70 \times 1,20 \mathrm{~mm}$.

Material selecionado. BRASIL. Bahia: Morro do

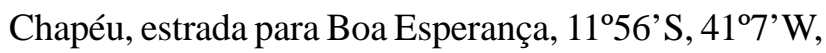
5/XII/2002, fl. fr., Junqueira et al. 177 (HUEFS).

Esta espécie ocorre apenas no Brasil com ampla distribuição, tendo sido referida para Maranhão, Piauí, Ceará, Alagoas, Bahia, Minas Gerais, Espírito Santo, São Paulo, Goiás, Mato Grosso e Mato Grosso do Sul. Em Morro do Chapéu foi encontrada na beira de estrada e em campo rupestre. Apesar de não ter sido coletada todos os meses, floresceu durante todo o período de excursões ao campo. Para outras áreas do Brasil floresce de outubro até junho e frutifica de abril a novembro.

Evolvulus pterocaulon é caracterizado pelas inflorescências espiciformes e congestas, pertence a um grupo de espécies muito semelhantes entre si (seção Lagopodini Meisn.), que além da inflorescência distinta, geralmente possui à base das folhas decorrentes. No município de Morro do Chapéu, essa espécie foi referida como medicinal, suas folhas são utilizadas para problemas no estômago ou digestórios.

\section{Agradecimentos}

Os autores agradecem aos curadores dos herbários citados pelo empréstimo e envio de material; à Universidade Estadual de Feira de Santana e Capes, pela bolsa concedida à primeira autora; aos professores Dr. Flávio França e Dra. Efigênia Melo, pelo auxilio durante o trabalho; ao Dr. André Márcio Amorim e aos dois assessores da revista, pelas sugestões dadas a este trabalho; a Delmar Alvim, pelo auxílio no campo; a Alano Calheira Durães, pelo auxílio nas ilustrações. 


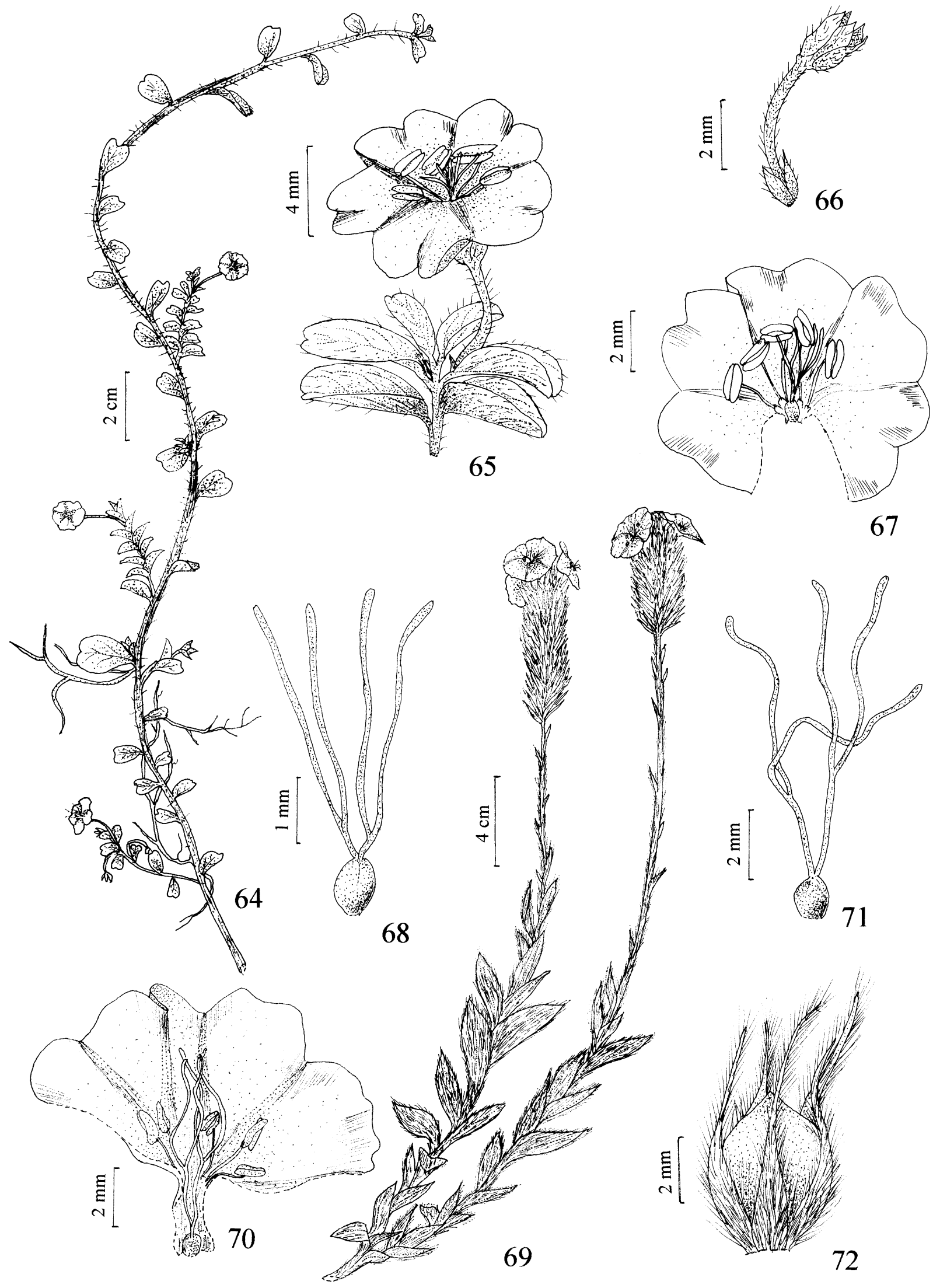

Figuras 64-72. Evolvulus pohlii: 64. Inflorescência. 65. Flor. 66. Pedicelo e cálice. 67. Corola aberta longitudinalmente. 68. Gineceu (Junqueira et al. 181). Evolvulus pterocaulon: 69. Hábito. 70. Corola aberta longitudinalmente. 71. Gineceu. 72 . Ovário (Junqueira et al. 177). 


\section{Referências bibliográficas}

Austin, D.F. 1982. Convolvulaceae. Family 165. Pp. 1-98. In: G. Harling \& B. Sparre (eds.). Flora of Ecuador, v.15, Opera botanica, Gothenberg.

Bahia. 2003. Anuário Estatístico da Bahia. Secretária do Planejamento. Superintendência de Estudos Econômicos e Sociais da Bahia, Salvador, v. 17.

Bandeira, R.L.S. 1995. Chapada Diamantina: história, riquezas e encantos. Salvador, Onavalis Editora.

Choisy, V.D.M.J.D. 1845. Convolvulaceae. Pp. 323-462. In: A.P. Candolle (ed.). Prodromus Systematis Naturalis Regni Vegetabilis, Parisiis, v.9.

Dafni, A. 1992. Pollination Ecology - The practical approach series. Oxford, Oxford University Press.

Falcão, J.I.A. 1977. Contribuição ao estudo das Convolvulaceae da Bahia. Rodriguésia 29(42): 41-101.

Hallier, H.J.G. 1893. Versuch einer naturlichen Gliederung der Convolvulaceen. Botanische Jahrbücher für Systematik Pflanzengeschichte und Pflanzengeographie 16: 479-591.

Harley, R.M. 1995. Introduction. Pp. 43-78. In: B.L. Stannard (ed.). Flora of the Pico das Almas - Chapada Diamantina, Bahia, Brazil. Kew, Royal Botanic Gardens.

Harley, R.M. \& Mayo, S.J. 1980. Towards a cheklist of the flora of Bahia. Kew, Royal Botanic Gardens.

Harley, R.M. \& Simmons, N.A. 1986. Florula of Mucugê Chapada Diamantina, Bahia, Brazil. Kew, Royal Botanic Gardens.

Harris, J.G. \& Harris, M.W. 1997. Plant identification terminology an illustrated glossary. $5^{\text {th }}$ ed., Spring Lake, Spring Lake Publishing.

Holmgren, P.K.; Holmgren, N.H. \& Barnett, L. 1990. Index herbariorum. Part 1: The Herbaria of the world. $8^{\text {th }}$ ed. New York, New York Botanical Garden.

Joly, A.B. 1970. Conheça a vegetação brasileira. São Paulo, EDUSP e Polígono.

Judd, W.S.; Campell, C.S.; Kellogg, E.A; \& Stevens, P.F. 1999. Plant systematics: a phylogenetic approach. Sunderland, Sinauer Associates.

Junqueira, M.E.R. \& Simão-Bianchini, R. 2003. Convolvulaceae. In: F. França; E. Melo; A.G. Neto; D. Araújo; M.G. Bezerra; H.M. Ramos; I. Castro \& D. Gomes. Flora vascular de açudes de uma região do Semi-Árido da Bahia, Brasil. Acta Botanica Brasilica 17(4): 549-559.
Köppen, W. 1948. Climatologia. México, Ed. Fondo de Cultura Económica.

Macbride, J.F. 1959. Convolvulaceae. In: J.F. Macbride. Flora do Peru. Publications of the Field Museum of Natural History, Botanical Series 13(5/1): 469-476.

Maury, C.M. (org.). 2002. Avaliação e identificação de áreas e ações prioritárias para conservação, utilização sustentável e repartição de benefícios da biodiversidade brasileira. Brasília, Ministério do Meio Ambiente.

Mori, S.A.; Silva, L.A.M.; Lisboa, G. \& Coradin, L. 1989. Manual de Manejo do Herbário Fanerogâmico. $2^{\text {a }}$ ed. Ilhéus, Centro de Pesquisas do Cacau.

Ooststroom, S.J.V. 1934. A monograph of the genus Evolvulus. Mededeelingen van het botanisch museum en herbarium van de rijks universiteit te Utrecht 14: 1-267.

Radford, A.E.; Dickison, W.C.; Massey, J.R. \& Bell, C.R. 1974. Vascular plant systematics. New York, Harper \& Rom Publishers.

Rocha, A.J.D. \& Costa, I.V.G. (org.). 1995. Projeto mapas municipais do município de Morro do Chapéu. Salvador, Companhia de Pesquisa de Recursos Minerais.

Simão-Bianchini, R. 1995. Convolvulaceae. Pp. 271-281. In: B.L. Stannard (ed.). Flora of the Pico das Almas - Chapada Diamantina, Bahia, Brazil. Kew, Royal Botanic Garden.

Simão-Bianchini, R. 1998. Convolvulaceae. Pp. 18 e 40. In: M.L.S. Guedes \& Orge, M.D.R. (eds.). Checklist das espécies vasculares do morro do Pai Inácio (Palmeiras) e Serra da Chapadinha (Lençóis), Chapada Diamantina, Bahia, Brazil. Salvador, Universidade Federal da Bahia.

Simão-Bianchini, R. 2002. Distribuição das espécies de Convolvulaceae na caatinga. Pp. 133-136. In: E.V.S.B. Sampaio; A.M. Giulietti; J. Virgínio \& C.F.L. GamarraRojas (eds.). Vegetação e flora da caatinga. Recife, APNE e CNIP.

Simão-Bianchini, R. 2003. Convolvulaceae. Pp. 368-369. In: D.C. Zappi; E. Lucas; B.L. Stannard; E.N. Lughadha; J.R. Pirani; L.P. Queiroz; S. Atkins; D.J.N. Hind; A.M. Giulietti; R.M. Harley \& A.M. Carvalho. Lista das plantas vasculares de Catolés, Chapada Diamantina, Bahia, Brasil. Boletim de Botânica da Universidade de São Paulo 21(2): 345-398

Stefanovic, S.; Krueger, L. \& Olmstead, R.G. 2002. Monophyly of the Convolvulaceae and circumscription of their major lineages based on DNA sequences of multiple chloroplast loci. American Journal of Botany 89(9): 1510-1522. 